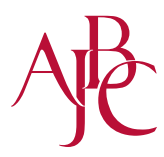

\title{
The Effects of Meridian Massage on Stress and Brain Activation of Middle-aged Women
}

\author{
Byung Nam Park, Seong Gyun Hong* \\ Department of Oriental Alternative Medicine, Nambu University, Gwangju-si, Jeollanam-do, Korea
}

*Corresponding author: Seong Gyun Hong, Department of Oriental Alternative Medicine, College of Health Science, Nambu University, 23 advanced Jungang-ro, Gwangsan-gu, Gwangjusi, Jeollanam-do 62271, Korea

Tel.: +82104482 1515

Fax: +82 629700166

Email: brainq@nambu.ac.kr

Received February 12, 2016

Revised March 14, 2016

Accepted March 17, 2016

Published March 30, 2016

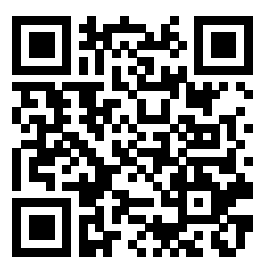

\begin{abstract}
Purpose: If our nerve cells are in a state of excitement because of internal and external reasons, secreted hormones, such as adrenaline, increase alertness and stress in brain. Thus, we aimed to investigate effects of meridian massage on stress and brain activation of middleaged women. Methods: There is still a lack of previous studies on meridian massage though it is widely used by researchers. So, we estimated electroencephalogram (EEG) before and after meridian massage targeting middle-aged women from February 2015. Results: The EEG results of the post-test are below. First, there was a significant effect of reducing the stress level in the middleaged women using meridian massage $(p<.05)$. Second, there was a significant effect of reducing variation in brain activation of a middleaged women using meridian massage ( $p$ <.001). Conclusion: We demonstrated that meridian massage had effects on stress and brain activation of middle-aged women.
\end{abstract}

Keywords: Middle-aged women, EEG, Stress, Meridian massage, Brain activation

\section{Introduction}

중년기는 인간의 성장 발달과정에서 인생의 전환점으로 특히 중년여성은 어느 시기보다도 내· 외적으로 다가오는 변화에 적 응해야 하는 부담과 폐경 및 노화현상 같은 신체적 변화를 겪게 되므로 많은 스트레스를 경험하게 된다(Choi, 2006). 복잡하고 다양한 현대사회를 살아가는 사람들은 일상생활에서 일어나는 여러 가지 스트레스로 인하여 신체질환은 물론 정신적인 질환까 지도 않고 있다. 스트레스가 질병수준이 아니라면 적절한 자기 관리가 필요하다(Lee, 2004). 최근 의학의 발달과 환경의 변화 및 사회 · 경제 수준의 향상으로 여성의 건강과 삶의 질이 사회 적인 측면에서 관심사로 대두 되고 있다. 웰빙 시장을 파고드는 '테라피'는 일반인들 즉, 보통의 생활을 영위하는 사람들을 위한 정신건강과 질병 예방 및 치유 차원의 건강을 제공하는 서비스 형태로 많이 시행되고 있다(Kim, 2006). 인간은 개개인의 스트 레스가 적응 반응에 따라 동일한 스트레스 원인에 대해서도 각 각 다른 다양한 반응을 나타내며, 더욱이 스트레스는 복잡한 현
대사회를 살아가는 동안에 피할 수 없는 삶의 한 부분이 되어 왔 다. 인체는 스트레스를 받으면 뇌에서 노르아드레날린이 분비되 며, 이 물질은 호르몬의 일종으로 대단히 강렬한 독성을 가지고 있다(Haruyama, 1999). 우리나라의 한 조사에 의하면 내과계 입원환자들의 약 $70 \%$ 가 스트레스로 인해 발병되거나, 기존의 신체적 지병이 악화되며 많은 환자들이 크고 작은 스트레스에 영향을 받는 것으로 나타났으며, 스트레스 자극으로 인해 몸 뿐 만 아니라 불안, 우울증 등 정서적 문제가 발생한다고 한다(Lee, 2006). 스트레스는 사람을 포함한 지구상의 모든 생물체에게 영 향을 주는 것으로 알려지고 있으며, 그 반응 정도와 미치는 영향 이 각각 다를 뿐이다. 장기간 불쾌한 나쁜 스트레스를 받게되면 신체적으로 여러 가지 질병을 일으키는 원인이 되기도 한다. 그 리고 스트레스가 동일하게 존재 하더라도 스트레스에 대처할 수 있는 내· 외적 자원에 따라 그 결과는 다른 양상을 보일 수 있 다. 선행연구에서 살펴보면, 자아 존중감 및 자아 탄력성(Kang, 2010), 자기효능감(Kim \& Cho, 2011), 문제 또는 정서대처방 식(Seo, 2011; Lazarus, 1993), 인지적 조절전략(Shim et al., 
2011) 등과 같은 개인 내적 자원에 따라 스트레스의 영향이 달 라지는 것으로 나타나고 있다(Cho, 2013). 대체의학 한 분류인 수기요법인 경락마사지는 인체의 에너지 즉 기의 흐름을 활발하 게 하여 혈액과 림프액의 흐름을 촉진시켜 신진대사와 면역기능 을 왕성하게 하고, 골격계의 이상이나 위치변형을 조절하여 치 료효과를 극대화하는 효과를 나타낸다. 스트레스 감소를 위해 사용된 가장 오래된 치료인 마사지는 손 또는 팔, 등, 전신에 적 용 할 수 있다. 이중 손은 가장 접근이 쉽고, 대뇌의 감각부위를 가장 넓게 차지하며, 이해와 공감을 전달하고 짧은 시간에 대상 자의 생리적, 심리적 이완효과를 볼 수 있고(Synder, 1995) 비 침습적이며 특별한 도구가 없어도 적용할 수 있는 장점이 있어 가장 많이 적용되는 신체부위이다. 따라서 인체의 모든 부분을 순환하는 12 경락에서 등 경락마사지는 스트레스로부터 발생되 는 현대인들의 각종 호르몬의 불균형을 자연스럽게 치유하며 독 소를 제거 하는 효과를 가져다 준다(Choi et al., 2009). 특히 등 중앙부에 흐르고 있는 방광경락은 각 경락이 가지고 있는 진단 점과 치료점인 12 경락의 혈이 모두 분포되어 있어서 등부위를 관리함으로써 전신의 기혈을 조절하며, 혈액순환을 촉진하고 스 트레스 완화와 진정효과를 주고 근육의 피로를 풀어준다. 그에 따른 효과가 경험적으로 증명되어 한방에서는 치료의 보조요법 으로도 유용하게 사용되고 있다(Kim, 2009).

이에 본 연구는 중년기 여성의 정신 건강은 건강한 사회의 초 석이 되는 기본적인 요소라 생각되어, 경락마사지가 중년여성 의 스트레스와 뇌활성에 미치는 영향을 알아보기 위하여 뇌파 측정을 통한 인체 생리학적 효과를 과학적으로 검토하는데 그 목적을 두고 연구하였으며, 중년기 여성의 정신 건강은 건강한 사회의 초석이 되는 기본적인 요소라 생각이되어 효과가 있는 지 규명하고자 시도되었다.

\section{1. 경락}

'경락'에 해당하는 영어 단어는 자오선을 뜻하는 'meridian'인 데, 이는 하늘의 질서와 인간의 긴밀한 관계를 반영한 것이다 (Shudo, 1990). 경락은 우리 몸의 기와 혈을 운행시키고 장부 와 사지 · 관절을 연결하고, 상하 - 내외를 이어주며 피부에까지 이른다. 경락은 경맥(經脈)과 락맥(絡脈)의 결합체이며 경맥은 경락의 주된 기둥이며 상하로 운행하며 심기(深氣)와 같이 인체 의 깊은 곳을 유주하며, 반면 락맥은 기혈이 좌우로 운행하며 경맥의 가지로 오장육부의 주재에 맞춰 전신에 산포하며 인체 의 각 부분과 연관되어 소속 장부를 조절해준다(Hong, 2001).

경락과 락맥은 마치 그물처럼 분포하고 있으며, 이 곳을 흐르 고 있는 인체 에너지를 기혈이라고 한다. 경락은 기혈의 운행통 로로 장부, 사지관절과 연락하며 상하내외를 소통시켜 인체 기 능을 조절하는 특수한 네트워크이다.

최근 대체요법에 대한 관심이 증가함에 따라 동양의학의
경락개념을 마사지에 연결시킨 경락마사지가 비만과 스트레 스 등에 대한 효과가 있다는 연구 결과가 보고되었다(Jang, 2009).

\section{2. 스트레스}

스트레스 개념은 학자들마다 견해가 다르며, 일반적으로 외 적인 자극에 대한 개인의 반응으로서의 스트레스, 환경과 개 인간의 상호 작용으로서의 스트레스 등으로 나누어 볼 수 있다 (Phillips, 1978). 스트레스는 원인에 대한 생리적 · 정서적 반 응으로 스트레스의 수준은 받아들이는 사람의 주관적 해석에 따라 많은 차이가 있을 수 있다. 미국의 심리학자 Lazarus와 Cohen(1977) 은 동일한 스트레스라도 개개인의 스트레스 요 인에 대한 인지적 평가에 따라 스트레스를 느끼는 것에 개인차 가 있음을 보고하였다. 스트레스는 크게 첫째, 생활이 불쾌하 거나 자극을 받았을 때 오는 스트레스 둘째, 어떤 상황에 직면 하여 심신에 일어나는 반응으로서의 스트레스 셋째, 극복할 수 없는 환경에 직면할 때 오는 스트레스로 분류할 수 있다(Oh et $a l, 2000)$. 스트레스에 대한 신체기관의 생리 반응은 스트레스 로 인한 자극이 대뇌피질에 전달되면 교감신경을 활성화시키며 일어난다. 교감신경이 활성화되면 시상하부를 통하여 뇌하수체 전엽과 후엽으로 전달되어 뇌하수체 후엽에서는 항이뇨 호르몬 의 분비를 촉진시키고, 뇌하수체 전엽에서는 부신피질 자극호 르몬이 분비되어 부신 피질에 있는 여러 가지 선 세포들을 자극 시켜 모든 기관의 혈관을 수축시켜 심근의 수축력이 강화되고 심박동수가 증가하며 혈압이 상승하게 된다(Oh, 1985).

\section{3. 뇌파 (EEG, Electroencephalogram)}

뇌파는 두피에서 자발적으로 발생하는 전위(electric potential)로 뇌신경세포의 활동에 수반되어 생성되는 전기적 변화를 머리표면에 부착한 전극에 의해 비침습적인 방법으로 측정하는 전기신호이다. 따라서 뇌파는 대뇌에서 발생하는 전 기 현상을 두피에서 기록하고 뇌의 전기, 생리적 현상을 분석 하며 정신활동의 상태를 평가함으로서 뇌파상 변화를 가져다 주는 요인을 개인차, 연령, 의식상태의 변화, 정신활동, 신체의 생리적 생화학적 변화, 혹은 질환상태 등으로 정의한다(Yun, 2012). 뇌파는 크게 자발뇌파와 유발뇌파로 구분 할 수 있다. 일반적으로 뇌파는 두피상에서 측정하기 때문에 자발뇌파가 섞 여있고 피험자의 움직임이나 생리적인 다른 신호의 영향에 인 하여 유발뇌파를 얻는 것은 매우 어려운 일이다. 이는 인지과정 혹은 정보처리 과정에서 가장 많이 연구되고 있다(Humphrey \& Kramer, 1994). 또한 뇌파는 나이에 따라 몇 가지 특별한 파형을 나타내기도 한다. 유아기에는 $\alpha$ 파보다 $\theta$ 파가 두드러지 게 나타나고, 20 세부터 60 세까지는 뇌파의 기본 패턴으로 안정 된 양상을 보이다가 노년기에 $\delta$ 파가 증가하고 알파 리듬주기에 
도 연장을 보여 전반적인 주파수가 돌출성, 반응성에서 감소를 보이게 된다(Kim, 2002).

\section{Methods}

\section{1. 연구 대상}

경락마사지가 중년여성의 스트레스와 뇌활성에 미치는 영향 을 알아보기 위하여 본 연구를 실시하였다. 실험군과 대조군을 각각 12 명씩 선정하였으나, 최종분석 대상자 수는 실험군 11 명, 대조군 12 명으로 실험군 중 1 인은 실험기간 중 개인 사정으 로 인하여 지속할 수 없었다. 각 군은 1 달여간 뇌파 분석실험을 시행하였으며 실험에 앞서 영향을 줄 수 있는 음주 및 흡연을 가능한 배제하였다.

\section{2. 연구 방법}

임상실험 과정을 먼저 설명한 후 뇌파 등에 영향을 미치지 않 도록 하였고, 1 주일 간격으로 경락마사지를 실시하였다. 뇌파 측정 전 충분한 휴식과 설명 후 국제 전극 배치법에 의하여 머 리표면에 10/20 측정전극을 차례대로 부착하고, 측정 도중 외 부소음과 피험자의 움직임으로 인한 오류발생 시에는 반복 측

Table 1. The effect of meridian massage on stress

\begin{tabular}{|c|c|c|c|c|c|}
\hline Division & & Average & $\begin{array}{l}\text { Standard } \\
\text { deviation }\end{array}$ & $F$ & $p$ \\
\hline \multirow{5}{*}{ Prefrontal } & 1. & 22.10 & .671 & \multirow{5}{*}{7.226} & \multirow{5}{*}{$.026\left(^{*}\right)$} \\
\hline & 2. & 24.41 & .643 & & \\
\hline & 3. & 24.12 & .775 & & \\
\hline & 4. & 22.23 & .267 & & \\
\hline & 5. & 22.56 & .357 & & \\
\hline \multirow{5}{*}{ Frontal } & 1. & 20.21 & .704 & \multirow{5}{*}{20.374} & \multirow{5}{*}{$.003\left(^{*}\right)$} \\
\hline & 2. & 22.74 & .073 & & \\
\hline & 3. & 22.06 & .382 & & \\
\hline & 4. & 20.58 & .228 & & \\
\hline & 5. & 20.09 & .016 & & \\
\hline \multirow{5}{*}{ Temporal } & 1. & 25.86 & 1.916 & \multirow{5}{*}{.722} & \multirow{5}{*}{.613} \\
\hline & 2. & 27.05 & 2.163 & & \\
\hline & 3. & 27.33 & 1.033 & & \\
\hline & 4. & 24.84 & 2.467 & & \\
\hline & 5. & 25.05 & 1.498 & & \\
\hline \multirow{5}{*}{ Occipital } & 1. & 21.45 & .933 & \multirow{5}{*}{21.440} & \multirow{5}{*}{$.002\left({ }^{* *}\right)$} \\
\hline & 2. & 24.28 & .538 & & \\
\hline & 3. & 23.37 & .325 & & \\
\hline & 4. & 20.91 & .196 & & \\
\hline & 5. & 20.37 & .016 & & \\
\hline
\end{tabular}

${ }^{*} \mathrm{p}<.05,{ }^{* *} \mathrm{p}<.01$
정하였다. 마사지는 호흡의 깊이와 호흡의 속도, 호흡의 압력으 로 진행하였으며, 1 회 30 분간 1 동작 5 가지 기본동작(쓸어주기, 밀착해서 쓸어주기, 두드리기, 주무르기, 털어주기)을 중심으로 3-5회유지 동작하였다. 마사지 유지 시 기의 흐름이 끊기지 않 도록 하며, 자세 이동시피시술자에게서 손이 떨어지지 않게 하 였다.

\section{Results and Discussion}

\section{1.경락마사지를 이용한 중년여성의 스트레스 정도 감소 변화 에 유의한 효과}

경락마사지 실시 전 · 후 실험군과 대조군의 스트레스 정도를 살펴보면 전전두엽의 경우에 2 차와 3 차가 높게 나타났고, 1 차, 4 차, 5 차는 낮게 나타났으며 유의한 차이를 보였다(p<.05). 전 두엽의 경우에는 2 차와 3 차가 높게 나타났으며, 1 차, 4 차, 5 차 는 상대적으로 낮게 나타났다(p<.05). 또한 후두엽은 2 차가 높 게 나타났으며 4차, 5 차가 상대적으로 낮게 나타나 유의한 차 이를 보임을 알 수 있었다(p<.01).

Table 2. The effect of meridian massage on brain activation

\begin{tabular}{|c|c|c|c|c|c|}
\hline Division & & Average & $\begin{array}{l}\text { Standard } \\
\text { deviation }\end{array}$ & $F$ & $p$ \\
\hline \multirow{5}{*}{ Prefrontal } & 1. & 9.59 & .017 & & \multirow{5}{*}{$\begin{array}{l}.003 \\
(* *)\end{array}$} \\
\hline & 2. & 12.01 & .685 & & \\
\hline & 3. & 10.21 & .048 & 20.892 & \\
\hline & 4. & 9.64 & .073 & & \\
\hline & 5. & 9.93 & .028 & & \\
\hline \multirow{5}{*}{ Frontal } & 1. & 9.49 & .441 & & \multirow{5}{*}{$\begin{array}{l}.001 \\
(* * *)\end{array}$} \\
\hline & 2. & 11.65 & .057 & & \\
\hline & 3. & 10.24 & .132 & 35.409 & \\
\hline & 4. & 9.44 & .126 & & \\
\hline & 5. & 9.84 & .029 & & \\
\hline \multirow{5}{*}{ Temporal } & 1. & 10.54 & .082 & & \multirow{5}{*}{$\begin{array}{l}.000 \\
(* * *)\end{array}$} \\
\hline & 2. & 12.46 & .033 & & \\
\hline & 3. & 11.12 & .152 & 98.123 & \\
\hline & 4. & 10.19 & .208 & & \\
\hline & 5. & 10.57 & .086 & & \\
\hline \multirow{5}{*}{ Occipital } & 1. & 10.32 & .084 & & \multirow{5}{*}{$\begin{array}{l}.000 \\
(* * *)\end{array}$} \\
\hline & 2. & 13.21 & .055 & & \\
\hline & 3. & 11.23 & .165 & 182.370 & \\
\hline & 4. & 10.50 & .206 & & \\
\hline & 5. & 10.46 & .006 & & \\
\hline
\end{tabular}

${ }^{* *} \mathrm{p}<.01,{ }^{* * *} \mathrm{p}<.001$ 


\section{2. 경락마사지를 이용한 중년여성의 뇌활성 감소 변화에 유의 한 효과}

경락마사지 실시 전·후 실험군과 대조군의 뇌활성을 살펴 보면 전전두엽의 경우에 2 차가 높게 나타났고, 1 차, 4 차, 5 차 가 낮게 나타났으며 유의한 차이를 보였다(p<.01). 전두엽의 경 우에는 2 차가 높게 나타났으며, 1 차, 4 차, 5 차는 상대적으로 낮게 나타났다( $\mathrm{p}$ <.001). 측두엽은 2 차가 높게 나타났고 1차, 4 차, 5 차가 상대적으로 낮게 나타나며 유의한 차이를 보였다 ( $\mathrm{p}$ <.001). 후두엽은 2 차가 높게 나타나며 4차, 5 차가 상대적으 로 낮게 나타나 유의한 차이를 보임을 알 수 있었다(p〈.001).

\section{Conclusion}

본 연구의 목적은 경락마사지를 이용한 중년여성의 스트레 스 및 뇌활성의 변화를 규명하고자 진행되었다. 경락마사지는 널리 보급되어 있지만 아직 선행연구가 부족하여 본 연구자는 2015년 2월부터 중년여성들을 대상으로 M 피부 관리실에서 시 행을 하였다. 총 연구 대상자는 23 명으로 실험군 $(\mathrm{N}=11)$, 대조 군 $(\mathrm{N}=12)$ 으로 나누어 실험을 설계하였다. 5 번에 걸친 경락마 사지를 통하여 각 군에 실시한 사후검사에 따른 뇌파 분석 결과 다음과 같은 결론이 도출되었다.

첫째, 경락마사지를 이용한 중년여성의 스트레스 정도 감 소 변화에 유의한 효과가 있었다(p<.05). 둘째, 경락마사지를 이용한 중년여성의 뇌활성 감소 변화에 유의한 효과가 있었다 ( $p<.001)$. 이와 같은 연구 결과를 통해 경락마사지가 중년여성 의 스트레스 및 뇌활성에 효과가 있음을 알 수 있었다. 또한 선 행 연구에 따르면 스트레스나 우울증 환자는 우측 전두엽의 활 동도가 좌측에 비하여 높고, 우측 두정엽의 활동도가 상대적으 로 낮다는 보고가 있었다(Smit et al., 2007). 또 다른 선행연 구에서는 스트레스와 우울증의 척도 검사 실시에서 우측 두정 엽-측두엽의 저활동성과 밀접한 관련성이 있지만 뇌파에 대한 영향은 우울증상과 스트레스가 서로 상반된 것으로 나타났다 (Kessler et al., 2003). 차후 실험규모를 확대하고 증상 및 다 양한 기법에 따라 실험연구가 이루어지길 기대하며 향후 뇌파 변화의 따른 정확한 연구가 필요할 것으로 사료된다.

\section{References}

Choi BY, Seo SH, Choi MO. The study for muscular body type change after back meridian massage of obese female college students. Journal of the Korean Society of Cosmetology, 15: 1214-1219, 2009.
Cho HJ. A study on the stress involved in preparing for employment on college student's happiness: the moderating effects of social support. Studies on Korean Youth, 24: 157-184, 2013.

Haruyama S. A great revolution in the brain world. People and books, Seoul, pp28, 1999.

Hong SG. Meridian skin cosmetology ( I). DaihakSeorim, Seoul, pp77-81, 2001.

Humphrey DG, Kramer AF. Toward a psychophysiological assessment of dynamic changes in mental workload. Human Factors, 36: 3-26, 1994.

Kessler RC, Berglund P, Demler O, Jin R, Koretz D, Merikangas KR, Rush AJ, Walters EE, Wang PS. The epidemiology of major depressive disorder: results from the national comorbidity survey replication (NCS-R). Journal of the American Medical Association, 289: 3095-3105, 2003.

Kim KW, Cho YH. Mediation and moderation effects of self-efficacy between career stress and college adjustment among freshmen. Korean Journal of Youth Studies, 18: 197-218, 2011.

Kim KY. Effect of aesthetic meridian massage for relaxation to mood state. Journal of the Korean Society of Cosmetology, 15: 123-133, 2009.

Lazarus RS, Cohen JB. Environment stress. In: Human behavior and environment. Altman I \& Wohlwill JF (Eds.), Plenum Publ. Corp., New York, 1977.

Lee KS. A research on aesthetic approaching method of Ayurveda. Journal of the Korean Society of Fashion \& Beauty, 2: 57-64, 2004.

Oh GS. Stress and applied theory. Nursing association, Seoul, pp41-45, 1985.

Oh JS, Lee SK. A study on mitigation of abdominal obesity of abdominal meridian massage. Korean Journal of Aesthetics and Cosmetology, 7: 127-136, 2009.

Phillips BN. Educational and psychological perspectives on stress in students, teachers, and parents. Clinical Psychology Publ. Corp., USA, 1993.

Seo KH. Relationships between stresses, problem-focused coping, upward/downward comparison coping and subjective well-being of college students. Korean Journal of Youth Studies, 18: 217-236, 2011.

Shim JE, An HY, Kim JH. The relationship between Job- 
seeking stress and depression in college students: the mediating roles of cognitive emotion regulation strategies. Journal of Human Understanding and Counseling, 32: 103-118, 2011.

Smit DJ, Posthuma D, Boomsma DI, De Geus EJ. The relation between frontal EEG asymmetry and the risk for anxiety and depression. Biological Psychology, 74: 26-33, 2007.

Snyder M, Egan EC, Burns KR. Efficacy of hand massage in decreasing agitation behaviors associated with care activities in persons with dementia. Geriatric Nursing, 16: 60-63, 1995. 


\section{국문초록}

\section{경락마사지가 중년여성의 스트레스와 뇌활성에 미치는 영향}

박병남, 홍성균*

남부대학교 대체의학과, 전라남도 광주광역시, 한국

목적: 내 · 외적인 이유로 신경세포가 과도하게 흥분상태가 되면, 아드레날린과 같은 호르몬 분비로 인해 뇌조직의 각성도와 스트레 스가 증가하게 된다. 따라서, 본 연구는 경락마사지를 이용한 중년여성의 스트레스 및 뇌활성의 변화를 규명하는데 그 목적이 있다. 방법: 녹경락마사지는 널리 보급되어 있지만 아직 선행연구가 부족한 실정이다. 그래서 본 연구자는 2015년 2월부터 중년여성들을 대상으로 경락마사지 적용 전후 뇌파 측정을 실시하였다.

결과: 사후검사에 따른 뇌파 분석 결과는 다음과 같다. 첫째, 경락마사지를 이용한 중년여성의 스트레스 정도 감소에 유의한 효과가 있었다(p<.05). 둘째, 경락마사지를 이용한 중년여성의 뇌활성 감소 변화에 유의한 효과가 있었다(p<.001).

결론: 경락마사지가 중년여성의 스트레스 및 뇌활성에 효과가 있음을 증명하였다.

핵심어: 중년여성, 뇌파, 스트레스, 경락마사지, 뇌활성

\section{참고문헌}

김경연. 긴장이완을 위한 미용경락시술이 기분상태에 미치는 효과. 한국미용학회지, 15: 123-133, 2009.

김경욱, 조윤희. 대학신입생의 진로스트레스와 대학생활적응과의 관계에서 자기효능감의 매개 및 조절효과. 청소년학연구, $18:$ 197-218, 2011.

서경현. 대학생의 스트레스, 문제중심 대처 및 상/하향비교 대처와 주관적 웰빙 간의 관계. 청소년학연구, 18: 217-236, 2011.

심지은, 안하얀, 김지혜. 대학생의 취업 스트레스와 우울 간의 관계: 적응적인 인지적 정서조절 전략의 매개효과 검증. 인간이해, 32: 103-118, 2011.

오정숙, 이시경. 복부경락마사지의 복부비만완화에 관한 연구. 대한피부미용학회지, 7: 127-136, 2009.

이계숙. 아유르베다의 피부미용 접근방법에 관한 고찰. 한국패션뷰티학회지, 2: 57-64, 2004.

조혜정. 대학생의 취업스트레스가 행복감에 미치는 영향: 사회적 지지의 조절효과. 한국청소년연구, 24: 157-184, 2013.

최부영, 서승희, 최미옥. 비만여대생의 등경락마사지 후 근체형 변화 연구. 한국미용학회지, 15: 1214-1219, 2009. 


\section{中文摘要}

\section{经络按摩对中年女性的大脑压力及大脑活性的影响}

朴炳南, 洪姓均*

南部大學敎 替代醫學科, 全罗南道光州广域市, 韩国

目的: 神经细胞因内外因素处于过分兴奋状态时, 会分泌像肾上腺素类似的荷尔蒙, 使增加脑组织的机敏性和大脑压力。研究 阐明经络按摩对中年女性的大脑压力和大脑活性变化的影响。

方法: 虽然经络按摩已得到广泛地应用, 但关于它的先行研究确相对缺乏。因此从2015年2月开始对中年女性进行脑波测定来 分析经络按摩使用前后。

结果: 使用经络按摩之后脑波分析结果如下 : 第一, 使用经络按摩之后中年女性的大脑压力明显缓解; 第二, 使用络按摩之后中 年女性的大脑活性也明显降低。

结论: 经络按摩对中年女性的大脑压力和大脑活性具有明显改善效果。

关键词: 中年女性, 脑波, 大脑压力, 经络按摩, 大脑活性 